\title{
IAMJ
}

INTERNATIONAL AYURVEDIC MEDICAL JOURNAL

\section{IMPORTANCE OF VAMAN KARMA W.S.R. BIOPURIFICATION - PREVENTION OVER INTERVENTION}

\author{
$\underline{\text { Vishal Aggarwal }}^{1}, \underline{\text { Tinkle Rani }}^{2}, \underline{\text { Arun Gupta }}^{3}$ \\ ${ }^{1}$ PG Scholar, ${ }^{2}$ PG Scholar, ${ }^{3}$ Professor and HOD, Panchakarma Department, CBPACS, New Delhi, India
}

Corresponding Author: tinklekhowal.tk@gmail.com

\section{https://doi.org/10.46607/iamj11p4062020}

(Published online: September 2020)

Open Access

(C) International Ayurvedic Medical Journal, India 2020

Article Received: 19/09/2020 - Peer Reviewed: 24/09/2020 - Accepted for Publication: 26/09/2020

\section{Check for updates}

\section{ABSTRACT}

Today's modern era life style is famous for its unhealthy lifestyle, improper sleep pattern, stressful life and so on, the reasons are uncountable so as the diseases, creating a high profile lifestyle with significant negative shift in health status which creates even more serious reasons to combat the pathology behind. Ayurveda is an age old timetested system of traditional medicine that comes with even more deep rooted three fold fundamental approach Nidan Parivarjana (avoidance of causative factors), Shodhan (biocleansing treatment modality) and Shaman (palliative treatment). Shodhan mainly comes under the broader terminology Panchakarma, may seem quite simple in its application yet creates effects that are powerful and long-lasting, very famous for its approach for various ailments, especially chronic disorders. As the name suggests Panchakarma comprises five therapeutic procedures namely Vamana, Virechana, Nasya, Basti and Raktamokshana. It acts as a bio servicing mechanism for the human body just like the regular servicing of the transport vehicle. In the present piece of work, Vaman Karma has been described w.s.r. to its importance as a therapeutic regime to eliminate toxins, acting as a biopurificatory technique to maintain and obtain health; and to remove ailments, a concept of prevention over intervention. Some concepts like mode of action, importance of Shodhanarth Sneh, etc; has also been discussed deeply to understand the working action behind them.

Keywords: Panchakarma, Vaman Karma, Biopurification. 


\section{INTRODUCTION}

The science of medicine is developing day by day, right from the investigation, prognosis and treatment of the disease, likewise diseases are also emerging in this modern era, which surely proves the inability of the modern high cost medical system to effectively impact the health as an improved state; which ultimately signals for the need of a more effective and approachable health scheme to come to the forefront

Panchakarma constitutes five therapeutic procedures predominantely having Shodhan effect by which vitiated dosha are expelled out thereby treating the condition from the root which is referred as biopurification. These are Vamana (intentional therapeutic vomiting), Virechana (therapeutic purgation), Nasya (Nasal drug delivery), Niruh Basti (medicated Enema) and Raktamokshana (therapeutic blood letting) ${ }^{1}$. Here Vaman Karma is deeply studied for its clinical efficacy on various disorders for various parameters. Vaman karma is a unique, natural, holistic, health-giving series of therapeutic treatments that cleanse the body's deep tissues of toxins, open the subtle channels, bring life-enhancing energy thereby increasing vitality, inner peace, confidence and well-being. Considering the benefits of vaman karma for diseased as well as for healthy persons, an attempt has been made here to understand the physiological changes during and after Vamana Karma.

\section{Need of Biopurification}

Acharya Charak has explained some symptoms where we need to give Shodhan therapy (biopurification). These signs are called as Bahudoshavastha (symptoms of exxagerated ill health condition $)^{2}$, comprising Indigestion, Anorexia, Obesity, Anemia, heaviness, exhaustion, eruption of pimples, wheals, pruritis, laziness, weakness, foul smell of the body, Utklesha (aggravation) of Kapha and Pitta Dosha, sleeplessness or excessive drowsiness, impotency, impairment to intelligence, inauspicious dreams, and loss of strength and complexion in spite of taking nourishing diet etc. Shodhan Karma has purification action on diseased as well as on healthy individuals and allows the biological system to return to homeostasis and to rejuvenate rapidly. In Charak Samhita Vimanasthana, Acharya Charak clearly mentioned about the Janpadodwansa and describes about the Vayu, Jala, Desha and Kala $D u s h t i^{3}$. With this he also mentioned the treatment for such conditions and adviced for Panchakarma. In the so called modern era, we can easily correlate this Vayu, Jala, Desha and Kala Dushti with the so many types of pollution like Vayu Dushti with air pollution and Jala Dushti with water pollution etc. Panchakarma is not just used for the treatment of Janpadodwansa but also to cure the ailments. So there is a critical need for understanding the biopurificatory mechanisms.

Figure 1: No. of Vaman Karma done

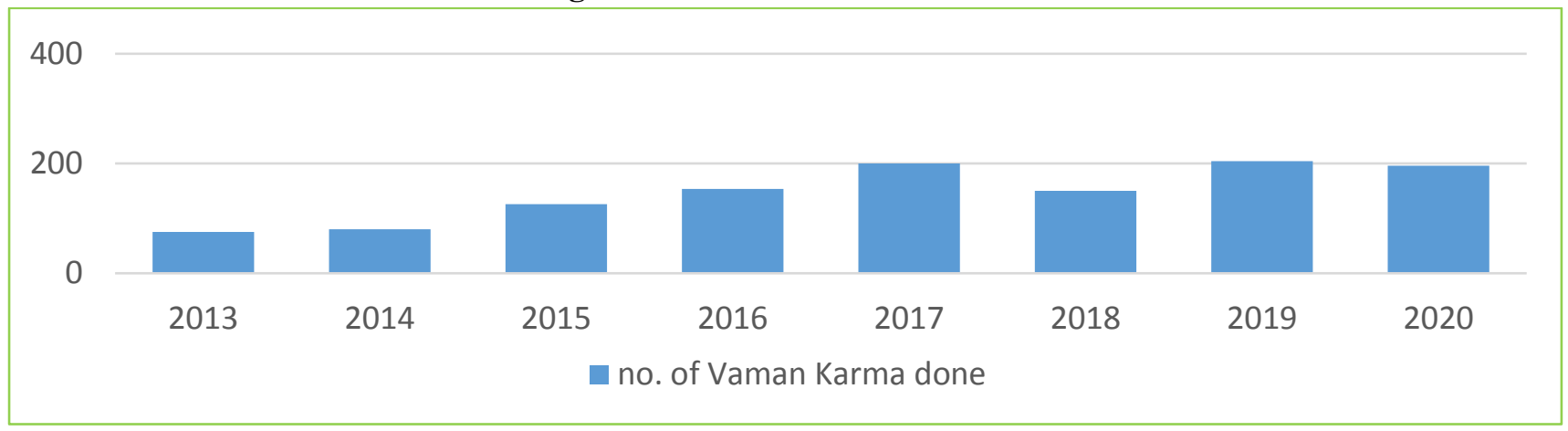

\section{Vaman Shatakam ${ }^{4}$}

Lot of work has already done by Panchakarma department of CBPACS on Vaman Karma. On $5^{\text {th }}$ march 2017 Vaman shatakam was organised at CBPACS in which Vaman of 142 participants was performed along with whole staff. Vaman procedure was done as per classical guidelines. It was surely a huge success not just for the department of Panchakarma, CBPACS but 
also for the whole Ayurveda community, to appreciate and motivate further, the event was recorded in Indian Book of Records as maximum number of Vamana therapies performed in a single day. This was just a stepping stone laid towards the never ending and ever ascending to do alot more work towards the betterment of the health care system, therefore every year Vasant Ritu (Spring Season) comes to CBPACS, with an opportunity to do a lot more; even in the Corona Crisis, the department was able to build such a huge number of record, with an early start and an early termination.

\section{SOP - Vaman Karma}

Examination and initial assessment of the patient

\section{Purvakarma (pre-procedural steps)}

1. Explanation of do's and don'ts to the patient.

2. Deepana Pachana-starting from three days till the achievement of Samyak Langhita Lakshanas (proper acheivment of the pre-requitistic status).

3. Antah Snehan (internal oleation): Shodhanarth Snehapana with prescribed Sneh (till the achievement of Samyak Snigdha Lakshana). Schedule of Antah Snehan (Shodhanarth Snehapana), With date, dose, time of sneh administration, Kshudha Kala and remarks (if any), must be recorde daily, strictly. Visrama Kala (resting period): one day previous t oVaman Karma. Kaphotkleshaka (increase in
1. Kapha Dosha amount) Diet - Dahi, milk, sweet dish like suji halwa, black gram.

2. Bahya Snehan (external oleation with prescribed oil as per the disease) and Swedan (as prescribed by the physician): for two days, on Vishrama Kala and on the Vaman day.

Pradhanakarma (main procedure): Vaman Karma day Manglacharan (sacred rituals to be performed) and Mantra Uccharan (Holy chanting and prayers), administration of milk (Akanthapana; filled upto the level of Gullet), Vaman Yoga- Madanaphala Pippli Churna (Antar Nakh Mushti) + Vacha Churna + Saindhava + Madhu (quantity sufficient), wait for one Muhurta ( 48 minutes) or till the first bout of vomiting and start Vamanopaga (drugs aiding in Vaman Karma) dravya (drugs) (e.g; Yashtimadhu Phanta) till Pittant condition. Final Koshtha Shudhi should be done with lukewarm Ushnodaka (hotwater). Assess for any complication and manage accordingly.

Paschatkarma: Wash Hands and face with Luke warm water, thereafter Dashmool Haridradi Dhoomapana (medicated fumigation) should be given. Prescribe Samsarjana Karma (post-procedural diet) as per the shudhi (type of purification) for 3, 5 and 7 days; of Peyadi Karma, Tarpanadai Karma or Rasadi Krama. Explanation of the Parihara Vishyas (do's and don'ts) and Ashta Maha Doshakar Bhava to be followed.

Figure 2: various steps of Vaman Karma in action

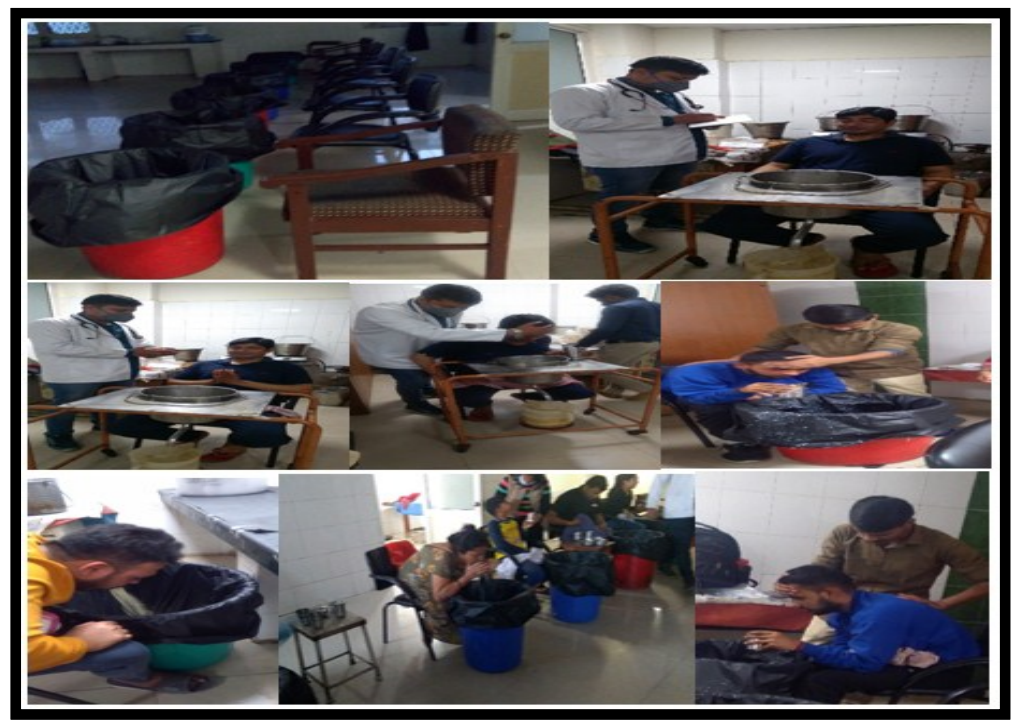




\section{DISCUSSION}

\section{Mode of Action of the Vaman Karma}

Same drug acts in different ways based on the route of administration. Action of the drugs is well described in the different texts of Ayurveda. The mechanism of the action of therapy as mentioned in Samhita (Ayurvedic treatise) is scientific if analysed in modern view considering the Physiology, Anatomy, Biochemistry etc. Mode of action describes a functional or anatomical change resulting from the exposure of a living organism to a substance.

\section{Ayurvedic view ${ }^{5}$}

The drugs for both Vamana Karma and Virechana Karma possess the five common qualities to be used in the action to carry out the act of Shodhana Karma, namely; Ushna (warm), Tiksna (sharp), Sukshma (minute), Vyavayi (fast pervading or diffusing) and Vikasi (getting dispersed all through the body). Acharya Sushurut adds in these five, the sixth quality namely, Sara (easily spreading nature) Gunn (quality). Individual action by these qualities are described as Ushna possess the action of Vilayan (melting), Vishyandan (mixing up) and liquefaction. In context of modern view, acts like catalyst agent i.e; converts saturated matter into the saturated one. Tikshna Gunn possess the action of Daha (burning), Paka (ripe), Srava (discharge) and Vichedana (disintegration). In view of modern perspective, breaking down the complex morbid Doshas (biohumors) into smaller molecules. Sukshma Gunn having Sukshma Sroto (micro channel) Gaami effect. In view of modern perspective, goes upto cellular level. Vyavayi property of drugs counts for its immediate initiation of action, irrespective of their digestion. Achraya Dalhan expailed this as completing the action without changing the original form i.e. with its Sampoorna (complete/ whole) Virya (potency). Vikasi Gunn loosened up the Dhatu Bandhatwa (binding capacity to the bodily tissues) of the Doshas. Sara is the property of Anulomatwa (regulation of the natural urges) i.e; the tendency of Vaman Karma.

Figure 3: Showing the factors responsible to carry out Vaman Karma acc. To Ayurvedic perspective

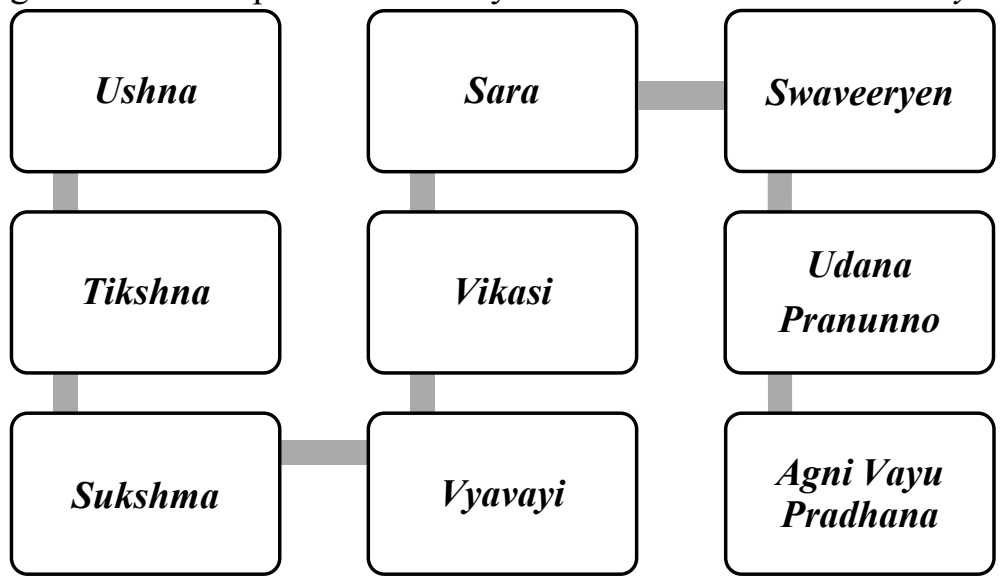

\section{Modern view}

In modern view, mode of action Vaman Karma is carried out by three ways

1. Mechanical stimulation

2. Chemical stimulation

3. Psychic stimulation

Mechanical stimulation starts by Akanthapana, which stretches out the stomach and overdistends and over ex- cites which further activates both sympathetic and parasympathetic affrents and thus stimulating the vomiting centre in medulla. Chemical stimulation is induced by the Vamaka Dravya itself by stimulating the CTZ which will further stimulates the vomiting centre in medulla. Psychic stimulation is by the taste and smell of the Vamaka Dravya which results in the Stimulation of higher cortical centres and thus stimulating the vomiting centre in medulla. Once the vomiting centre gets 
activated, there will be Stimulation of Autonomic motor efferents. Then there will be activation of the spinal and the cranial nerves which will result into the contraction of the upper GIT and the Diaphragm and thus the act of vomiting is carried out.

Figure 4: Showing the factors to carry out Vaman Karma acc. to Modern view
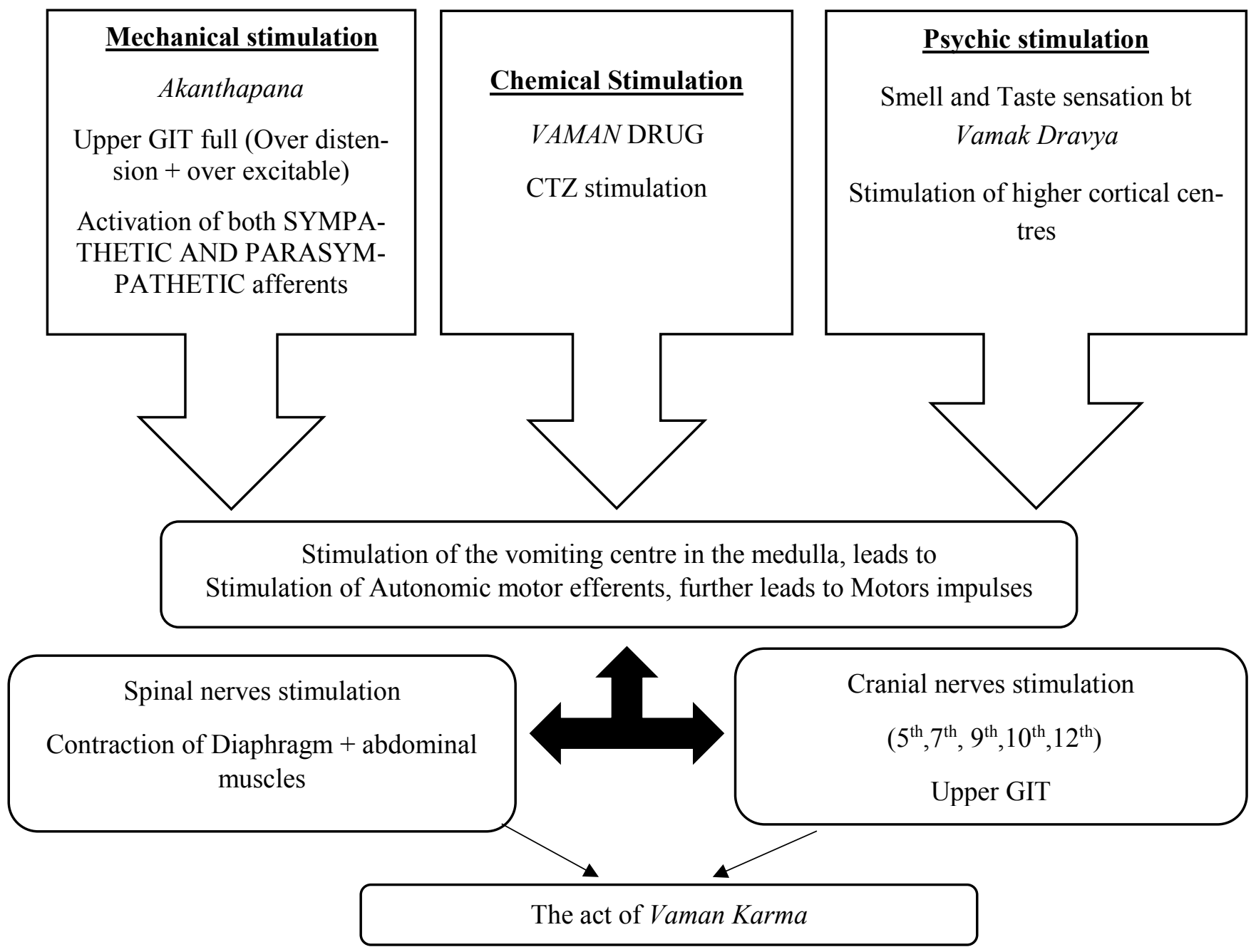

Role of fatty acids in Sneha (Lipid) digestion

There are mainly 4 types of fatty acids present in any type of fat namely short chain, medium chain, large chain and very large chain fatty acids. Among them fatty acids which contain less than 12 carbon atoms are considered in short and medium chain fatty acids and greater than $12 \mathrm{C}$ in long chain fatty acids. Short chain and medium chain fatty acids are mainly present in cow ghee and coconut oil substances. These fatty acids can be directly absorb in circulation whereas digestion of long chain fatty acids needs to pass first pass metabolism. Therefore cow ghee is advised for Abhyantara Snehana (internal oleation) in Vaman Karma.
The role of short-chain fatty acids in micro biotagut-brain communication ${ }^{7}$

Short-chain fatty acids (SCFAs) are speculated to have a mediational role in the microbiota-gut-brain axis crosstalk. SCFAs might influence psychological functioning via interactions with $G$ protein-coupled receptors which is also known as guanine nucleotide-binding proteins. These are a family of proteins that act as molecular switches inside cells, and are involved in transmitting signals from a variety of stimuli outside a cell to its interior and exert their effects on the brain via direct humoral effects, indirect hormonal and immune pathways and neural routes. 
Why we give one day rest after Snehapana (administration of Lipid for therapeutic purposes) for Vaman Karma?

As we know digestion of Sneha is with the help of bile produced by liver. When we increase the dose of Sneha during Snehpana Kala, amount of bile produced by liver also increased. When the Uttama Matra (maxim um expected dose) of Sneha is given on last day liver also has to produce more amount of bile to digest that. By giving rest we give rest to liver functions so that liver excrete morbid materials from the body on that rest day period. Bile is complex fluid containing water, elecrolytes, including bile acids, cholesterol, phospholipids and bilirubin. These substances are also secreted from the body by the help of bile. Adult human produces 400 to $800 \mathrm{ml}$ of bile daily. This quantity also increases at the time of Snehapana digestion. Hepatic syntheseis of bile acids account for majority of cholestrol breakdown from the body. This may be a major reason for fat reduction during Snehana (in obesity).

Role of Bile in decreasing the cholesterol levels...

Bile is a lipid-rich hepatic secretion that is necessary for elimination of cholesterol and xenobiotics from the body and for dispersion and efficient absorption of digested dietary lipid in the upper small intestine.

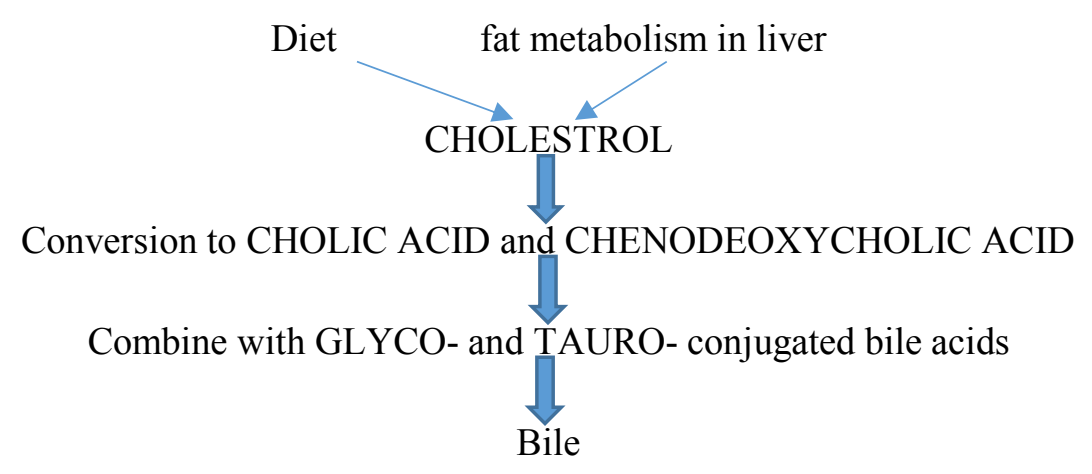

Taurine is efficient at reducing plasma and liver cholesterol concentrations ${ }^{8}$. The cholesterol-lowering effect of taurine is involved in the regulatory mechanism of cholesterol and bile acid homeostasis that is mediated by CYP7A1, which has become a biomarker for cholesterol metabolism and is itself also regulated by several factors and nuclear receptors. Therefore,

$$
\begin{gathered}
\text { More Snehpana } \\
\Downarrow \\
\text { more bile formation to digest } \\
\Downarrow \\
\text { increase taurine usage } \\
\Downarrow
\end{gathered}
$$

less cholesterol concentration in liver and plasma

\section{CONCLUSION}

The final take away message from the above piece of work suggests that Vaman Karma is not merely a thing for detoxification, but a fully well organised biopurificatory approach which is of keen importance for every individual whether diseased or appreantly well. Further the findings needs to be confirmed and validated on large scale to draw final conclusion for different parameters for Vaman Karma.

\section{REFERENCES}

1. Tripathi B. Dwividhiyopkarmaniya 14/5, In: Ashtang Hridyam of Shrimad vagbhatt. Varanasi: Chaukhambha Sanskrit Pratishthan; 2017.p. 135 
2. Shastri SN. Janapadodwansiyavimaan 3/56. In: Charak samhita of Agnivesha. Varanasi: Chaukhambha Bharti Academy 2011.p. 498

3. Shastri, K.N. Janpadodwansaniyavimanadyaya. In: Pandeya, G (ed.) Charak Samhita of Agnivesh. Varanasi, India: Chaukhambha Sanskrit Sansthan; 2012. p. 572.

4. WJPLS | Abstract [Internet]. [cited 2020 Feb 3]. Available from: https://www.wjpls.org/home/article_abstract/937

5. Shastri SN.Madanphalkalpa 1/5. In: Charak samhita of Agnivesha. Varanasi: Chaukhambha Bharti Academy 2011.p. 891

6. Shastri SN.Madanphalkalpa 1/5. In: Charak samhita of Agnivesha. Varanasi: Chaukhambha Bharti Academy 2011.p. 892

7. Dalile, B., Van Oudenhove, L., Vervliet, B. et al. The role of short-chain fatty acids in microbiota-gut-brain communication. Nat Rev Gastroenterol Hepatol 16, 461-478 (2019).
8. Reshetnyak VI. Physiological and molecular biochemical mechanisms of bile formation. World J Gastroenterol 2013; 19(42): 7341-7360 Available from: URL: http://www.wjgnet. com/10079327/full/v19/i42/7341.htm DOI: http://dx.doi. org/10.3748/wjg.v19.i42.7341.

\section{Source of Support: Nil \\ Conflict of Interest: None Declared}

How to cite this URL: Tinkle Rani et al: Importance Of Vaman Karma W.S.R. Biopurification - Prevention Over Intervention. International Ayurvedic Medical Journal \{online\} 2020 \{cited September, 2020\} Available from: http://www.iamj.in/posts/images/upload/2515 2521.pdf 